\title{
33. ESTIMATION OF GRAIN THERMAL CONDUCTIVITY IN THE TURBIDITE SEDIMENT OF THE JUAN DE FUCA RIDGE ${ }^{1}$
}

\author{
Masataka Kinoshita ${ }^{2}$
}

\begin{abstract}
Over 1000 thermal conductivity values were determined at four sites during Ocean Drilling Program Leg 139 exploration of Middle Valley, northern Juan de Fuca Ridge. Grain thermal conductivities were estimated from thermal conductivity and porosity data using the geometric mean model. In spite of large scatter in estimated grain conductivities, careful examinations of the data suggest that average grain conductivity at Hole $858 \mathrm{~A}$, located at the edge of a hydrothermal vent area, is higher by more than 0.5 $\mathrm{W} /(\mathrm{m} \cdot \mathrm{K})$ compared with that at other holes. This difference cannot be attributed to either the error in thermal conductivity measurements or the difference in mineral composition determined from the smear-slide description data. The higher value at Site 858 may reflect the influence of induration or cementation due to hydrothermal fluid flow at that site. Grain conductivities and grain densities are higher at all sites than those expected from mineral composition, which may result from regional hydrothermal metamorphism.
\end{abstract}

\section{INTRODUCTION}

Thermal conductivity was measured on samples cored during Leg 139, Juan de Fuca Ridge. A thick sequence of late Pleistocene sediments fills this rift valley and limits the exchange of seawater and crustal hydrothermal fluids (Davis and Villinger, 1992).

Holes were drilled at four sites (Fig. 1). Site 855, referred to as the recharge area, is located at the foot of the normal fault at the eastern margin of Middle Valley. Site 856 covers a relic massive sulfide mound and adjacent hill. Sites 857 and 858 are located in the axial part of Middle Valley. Site 858 is located at an active hydrothermal vent area. This paper focuses on estimating the influence of the different thermal and fluid-flow regimes at these sites on the grain thermal conductivity values.

Thermal conductivity is primarily a function of porosity. It is also a function of mineral composition, temperature and pressure, and degree of lithification or cementation. Thermal conductivity also correlates with bulk density and compressional-wave velocity (Horai, 1981), which vary primarily with porosity and changes in mineral composition. In the case of surficial, high-porosity sediment, a porosity change affects conductivity values most, but temperature and pressure are also important causes of changes in conductivity values, because Leg 139 holes have anomalously high temperatures. This problem is addressed in detail by Villinger et al. (this volume) and is not described here.

If mineral composition does not change with depth, porosity change due to sediment compaction is the dominant source of thermalconductivity variation. The relationship between thermal conductivity and porosity is well described mathematically by the geometric mean model (e.g., Horai, 1971). Using the geometric mean model, correlations were examined for all the conductivity and porosity data and grain thermal conductivities were estimated. The grain conductivity, which should reflect a certain physical or chemical change of constituent materials, is expected to be an indicator of hydrothermal effects such as induration, lithification, or cementation.

The influence of a variation in mineral composition on bulk grain conductivity values can be discussed if the volumetric fraction and the conductivity value of each mineral is determined. It is assumed that the

\footnotetext{
${ }^{1}$ Mottl, M.J., Davis, E.E., Fisher, A.T., and Slack, J.F. (Eds.), 1994. Proc. ODP, Sci. Results, 139: College Station, TX (Ocean Drilling Program).

${ }^{2}$ School of Marine Science and Technology, Tokai University, Shimizu-City Shizuoka, 424 Japan.
}

estimated bulk grain conductivity is equal to the geometric mean conductivity of constituent minerals (Brigaud and Vasseur, 1989). Proportions of constituent minerals were calculated from smear-slide data. A similar examination also was made of grain density, which, like grain conductivity, is considered to be a fundamental property of the solid matrix of the sediment.

\section{ESTIMATION OF GRAIN THERMAL CONDUCTIVITY USING THE GEOMETRIC MEAN MODEL}

Thermal conductivity and porosity are well correlated using the geometric mean model if the mineral composition and thus grain thermal conductivity do not vary significantly. The bulk thermal conductivity $K$ is expressed with the grain conductivity $K_{g}$, conductivity of water $K_{w}$, and porosity $\phi$ as:

$$
K=K_{w}^{\circ} \cdot K_{g}^{1-0}
$$

\section{Best-fit Method}

As a first step, the above equation is applied to measured conductivity and porosity values to estimate the "bulk" grain-thermal conductivity. Since index properties (bulk density, grain density, porosity, and water content) were not measured at exactly the same interval as thermal conductivity measurements, they were correlated within a window of $\pm 5 \mathrm{~cm}$ width. This lack of perfect coincidence could introduce error, especially where measurements were made near turbidite unit boundaries. Differences in estimated grain conductivity resulting from differences in window size may be as large as $10 \%$, judging by the difference of estimated grain conductivity between $\pm 5-\mathrm{cm}$ and $\pm 2-\mathrm{cm}$ windows for the data from Hole $858 \mathrm{~A}$. Samples cored by the extended core barrel (XCB) and the rotary core barrel (RCB) may be more disturbed than those cored by the hydraulic piston corer (HPC), so analyses were separated according to the coring method.

Figure 2 shows these correlations for the data obtained from HPC and XCB cores at Sites 856, 858, and Hole 857A, and from RCB cores at Holes $855 \mathrm{~A}$ through D and $857 \mathrm{C}$. Lines are the best-fit estimates according to the equation above. The best-fit grain thermal conductivity values are listed in Table 1 . Although plotted data have large scatter, they generally agree with the best-fit curve, implying that the grain component does not change drastically with change in 


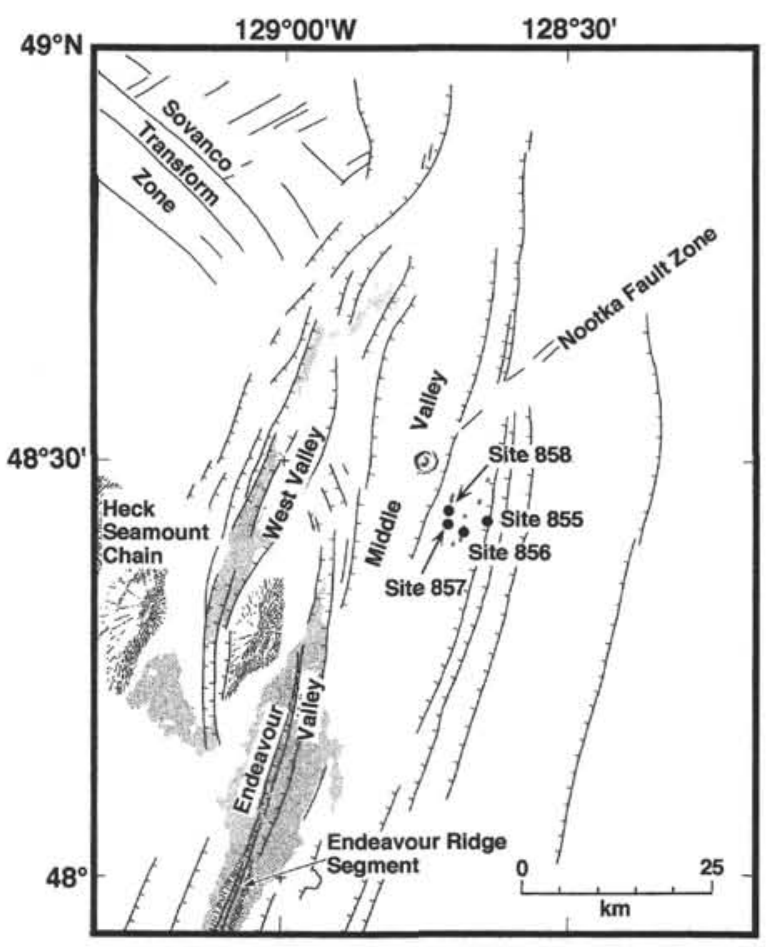

Figure 1. Index map showing the tectonic interpretation and the location of Leg 139 drilling sites (reproduced from Davis and Villinger, 1992).

porosity. On the other hand, the grain conductivity estimated from the $\mathrm{XCB}$ core of Hole $858 \mathrm{~A}$ (referred to hereafter as $858 \mathrm{~A}-\mathrm{X}$ ) is higher $(4.4 \mathrm{~W} /[\mathrm{m} \cdot \mathrm{K}])$ and the estimates from RCB cores (Site 855 and Hole $857 \mathrm{C})$ are lower $(3.1 \mathrm{~W} /[\mathrm{m} \cdot \mathrm{K}])$ as compared with those estimated from HPC cores (around $3.5 \mathrm{~W} /(\mathrm{m} \cdot \mathrm{K}$ ) at Holes 856A and 857A). Not enough data exists to give reliable estimates for other holes.

It is necessary, however, to consider whether these differences are statistically meaningful because of large scatter of thermal conductivities around the best-fit curve as shown in Figure 2 and because of the small number of correlated data (especially at Hole 858A-X). The cause of this large scatter may be the imperfect coincidence of sampling points between porosity and thermal conductivity (10\%, as mentioned above), error in thermal conductivity measurements (5\% to $10 \%$, Shipboard Scientific Party, 1992a), or actual variation of grain thermal conductivity vs. depth. Assuming that the total error is around $10 \%$, the above difference in grain conductivity, which is up to $20 \%$, may be statistically distinguishable. However, it is difficult to estimate accurately the total error of grain conductivity. Further- more, the above method does not hold when a mineral composition is not constant within each hole.

\section{Point-by-point Method}

As a next step, grain thermal conductivity values have been calculated point-by-point from the thermal conductivity and porosity value measured discretely using Equation 1. Figure 3 is their plots vs. depth (open circles), as well as grain conductivities estimated from smear-slide description (solid circles; see next section). Large scatter prevents us from recognizing any significant characteristics.

Histograms of the grain conductivity distribution binned at every $0.5 \mathrm{~W} /(\mathrm{m} \cdot \mathrm{K})$ are shown in Figure 4 to see if the populations at each hole are meaningfully separated. The average and the peak values of grain conductivity are listed in Table 1. As Figure 3 and Table 1 show, average grain conductivity values estimated by this point-by-point method basically agree with values estimated by the best-fit method mentioned above.

Grain conductivity for Holes $856 \mathrm{~A}, 856 \mathrm{~B}, 857 \mathrm{~A}$, and $857 \mathrm{C}$ peaks around $3.0-3.5 \mathrm{~W} /(\mathrm{m} \cdot \mathrm{K})$, whereas Hole $858 \mathrm{~A}$ peaks at $4.0-4.5$ $\mathrm{W} /(\mathrm{m} \cdot \mathrm{K})$. These peak values are generally lower than those obtained by the least-squares method. As seen in Figure 4, this is because the distribution of grain conductivity calculated at each point is not symmetrical and has a broader foot at higher values. Data from Site 855 peaks at $3.5-4.0 \mathrm{~W} /(\mathrm{m} \cdot \mathrm{K})$, which differs from that estimated by the best-fit method $(3.1 \mathrm{~W} /[\mathrm{m} \cdot \mathrm{K}])$; however, the large standard deviation of the values (Table 1) implies that the reliability of grain conductivity at Site 855 is relatively low.

The above analyses suggest that samples from Hole 858A (especially for the $\mathrm{XCB}$ cores) have higher grain thermal conductivity values, perhaps resulting from error in thermal conductivity measurements or difference in bulk mineral composition. These possibilities are discussed in the following sections.

\section{INFLUENCE OF ERROR IN THERMAL CONDUCTIVITY MEASUREMENTS ON GRAIN CONDUCTIVITY ESTIMATION}

High grain conductivity values at Hole $858 \mathrm{~A}$ (especially from $\mathrm{XCB}$ cores) may result from errors in thermal conductivity measurements. If any factor could bias measured conductivity values and thus the grain conductivities, the population at Hole $858 \mathrm{~A}-\mathrm{X}$ should be separated from that at other holes in the correlative plots of conductivity vs. that factor.

Several other factors are recorded during thermal conductivity measurements, such as needle-probe ID, standard error of needleprobe temperature during measurement, average temperature drift rate before measurements, and calculated temperature drift rate during

Table 1. Estimated grain thermal conductivity and grain density.

\begin{tabular}{|c|c|c|c|c|c|c|c|c|c|c|c|c|c|c|}
\hline \multirow[b]{2}{*}{ Hole } & \multirow[b]{2}{*}{ Type } & \multirow[b]{2}{*}{$\begin{array}{l}\text { Interval } \\
\text { (mbsf) }\end{array}$} & \multicolumn{4}{|c|}{ Geometric mean model } & \multicolumn{6}{|c|}{ Smear slide description } & \multicolumn{2}{|c|}{ Index properties } \\
\hline & & & $\mathrm{n}$ & $\begin{array}{l}\mathrm{K}_{g} \text { (bestfit) } \\
(\mathrm{W} /[\mathrm{m} \cdot \mathrm{K}])\end{array}$ & $\begin{array}{c}\mathrm{K}_{g} \text { (point) } \\
(\mathrm{W} /[\mathrm{m} \cdot \mathrm{K}])\end{array}$ & $\begin{array}{c}\text { Peak } \\
(\mathrm{W} /[\mathrm{m} \cdot \mathrm{K}])\end{array}$ & $\mathrm{n}$ & $\begin{array}{l}\text { Clay } \\
(\%)\end{array}$ & $\begin{array}{l}\text { Feldspar } \\
\text { (\%) }\end{array}$ & $\begin{array}{c}\text { Quartz } \\
(\%)\end{array}$ & $\begin{array}{c}\text { Grain } \\
\text { conductivity } \\
(\mathrm{W} /[\mathrm{m} \cdot \mathrm{K}])\end{array}$ & $\begin{array}{c}\text { Grain } \\
\text { density } \\
\left(\mathrm{g} / \mathrm{cm}^{3}\right)\end{array}$ & $n$ & $\begin{array}{c}\text { Grain density } \\
\left(\mathrm{g} / \mathrm{cm}^{3}\right)\end{array}$ \\
\hline $855 \mathrm{~A}-\mathrm{D}$ & $\mathrm{R}$ & $0-118.6$ & 79 & 3.10 & $3.62(1.11)$ & $3.5-4.0$ & & & & & & & 90 & $2.75(0.24)$ \\
\hline $856 \mathrm{~A}$ & $\mathrm{H}$ & $0-78.7$ & 47 & 3.48 & $3.60(0.90)$ & $3.1-3.2$ & & & & & & & 88 & $2.77(0.02)$ \\
\hline $856 \mathrm{~A}$ & $\mathrm{H}+\mathrm{X}$ & $0-115.7$ & 48 & 3.49 & $3.61(0.89)$ & $3.1-3.2$ & 50 & $31(31)$ & $26(17)$ & $26(17)$ & $3.00(0.68)$ & $2.66(0.01)$ & 94 & $2.77(0.03)$ \\
\hline $856 \mathrm{~B}$ & $\mathrm{H}$ & $0-70.8$ & 3 & 3.51 & $3.87(0.77)$ & & & & & & & & 14 & $2.79(0.02)$ \\
\hline $856 \mathrm{~B}$ & $\mathrm{H}+\mathrm{X}$ & $0-121.7$ & 4 & 3.40 & $3.72(0.69)$ & & & & & & & & 22 & $2.80(0.05)$ \\
\hline $857 \mathrm{~A}$ & $\mathrm{H}+\mathrm{X}$ & $0-111.2$ & 12 & 3.51 & $3.47(0.48)$ & $3.1-3.2$ & 32 & $29(28)$ & $11(13)$ & $21(15)$ & $2.88(1.12)$ & $2.71(0.21)$ & 23 & $2.75(0.02)$ \\
\hline $857 \mathrm{C}$ & $\mathrm{R}$ sed & $0-461.7$ & 36 & 3.14 & $3.21(0.42)$ & $3.2-3.6$ & 70 & $35(31)$ & $6(11)$ & $25(18)$ & $2.99(1.12)$ & $2.70(0.20)$ & 84 & $2.78(0.05)$ \\
\hline $858 \mathrm{~A}$ & $\mathrm{H}$ & $0-62.5$ & 12 & 3.61 & $3.77(0.76)$ & $4.0-4.5$ & & & & & & & 17 & $2.71(0.03)$ \\
\hline $858 \mathrm{~A}$ & $\mathrm{X}$ & $62.5-339.1$ & 8 & 4.40 & $4.48(0.79)$ & $4.0-4.5$ & 24 & $35(31)$ & $6(9)$ & $21(16)$ & $3.15(0.95)$ & $2.71(0.07)$ & 22 & $2.78(0.04)$ \\
\hline $858 \mathrm{~A}$ & $\mathrm{H}+\mathrm{X}$ & $0-339.1$ & 20 & 4.18 & $4.05(0.83)$ & $4.0-4.5$ & 47 & $33(30)$ & $4(7)$ & $21(17)$ & $3.02(0.82)$ & $2.71(0.06)$ & 39 & $2.75(0.05)$ \\
\hline $858 \mathrm{~B}-\mathrm{D}$ & $\mathrm{H}+\mathrm{X}$ & & 12 & 3.67 & $3.99(1.22)$ & $3.5-4.0$ & 55 & $56(30)$ & $1(4)$ & $11(18)$ & & & 54 & $2.70(0.03)$ \\
\hline
\end{tabular}

Note: $\mathrm{n}=$ Number of data samples; $(\mathrm{)}=$ standard deviation; $\mathrm{R}=\mathrm{RCB}, \mathrm{H}=\mathrm{HPC}, \mathrm{X}=\mathrm{XCB} ; \mathrm{Kg}($ bestfit $)=$ best-fit estimates of grain thermal conductivity using the geometric mean model; $\mathrm{Kg}($ point $)=$ mean grain conductivity estimated point-by-point using the geometric mean model; Peak = peak values of histogram (see Fig. 4 ). 

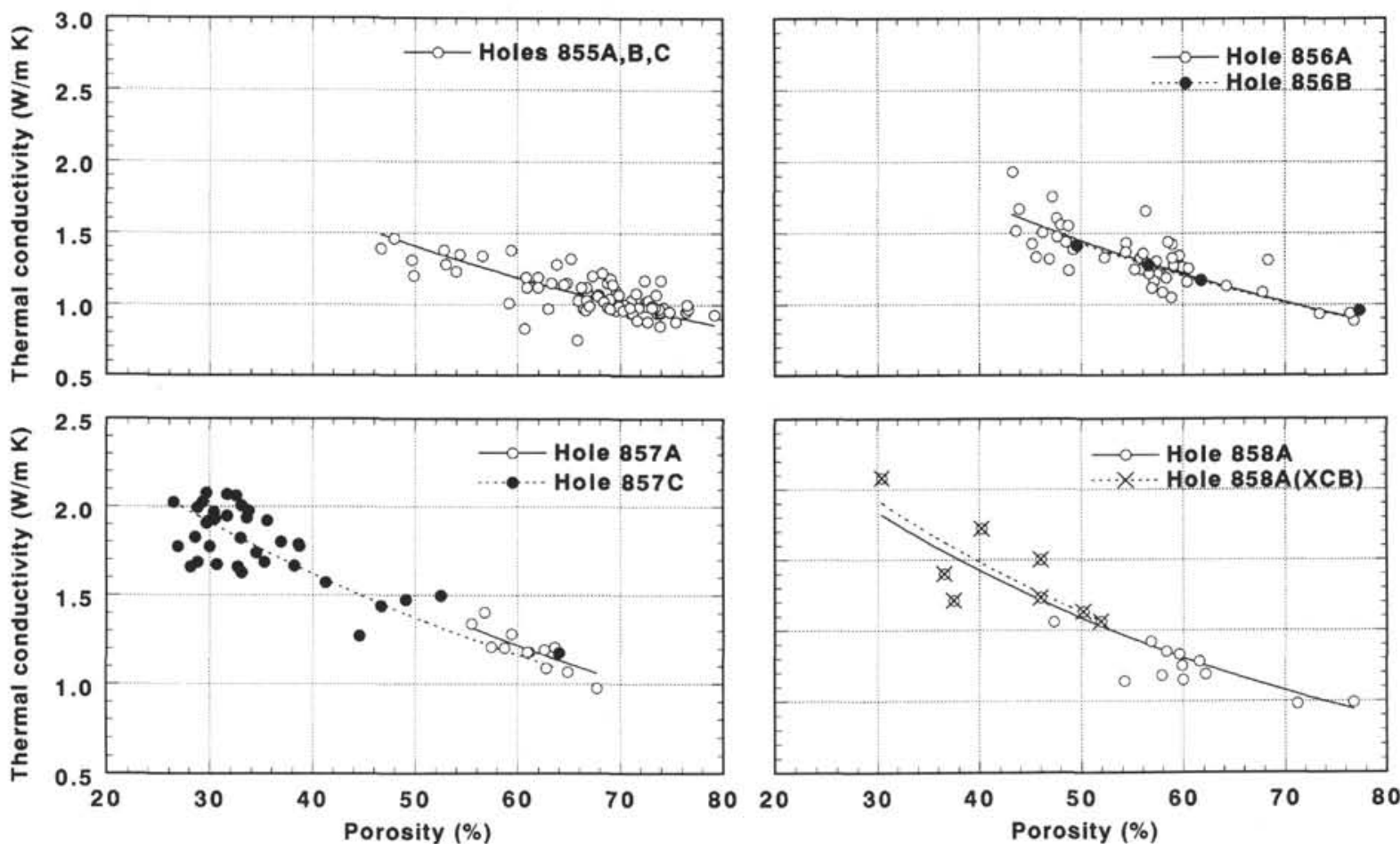

Figure 2 . Thermal conductivity vs. porosity measured for Sites $855,856,857$ and 858 . Lines are the best-fit estimates by the geometric mean model. Only data obtained from HPC cores are plotted for Holes 856A, 856B, 857A, and 858A.
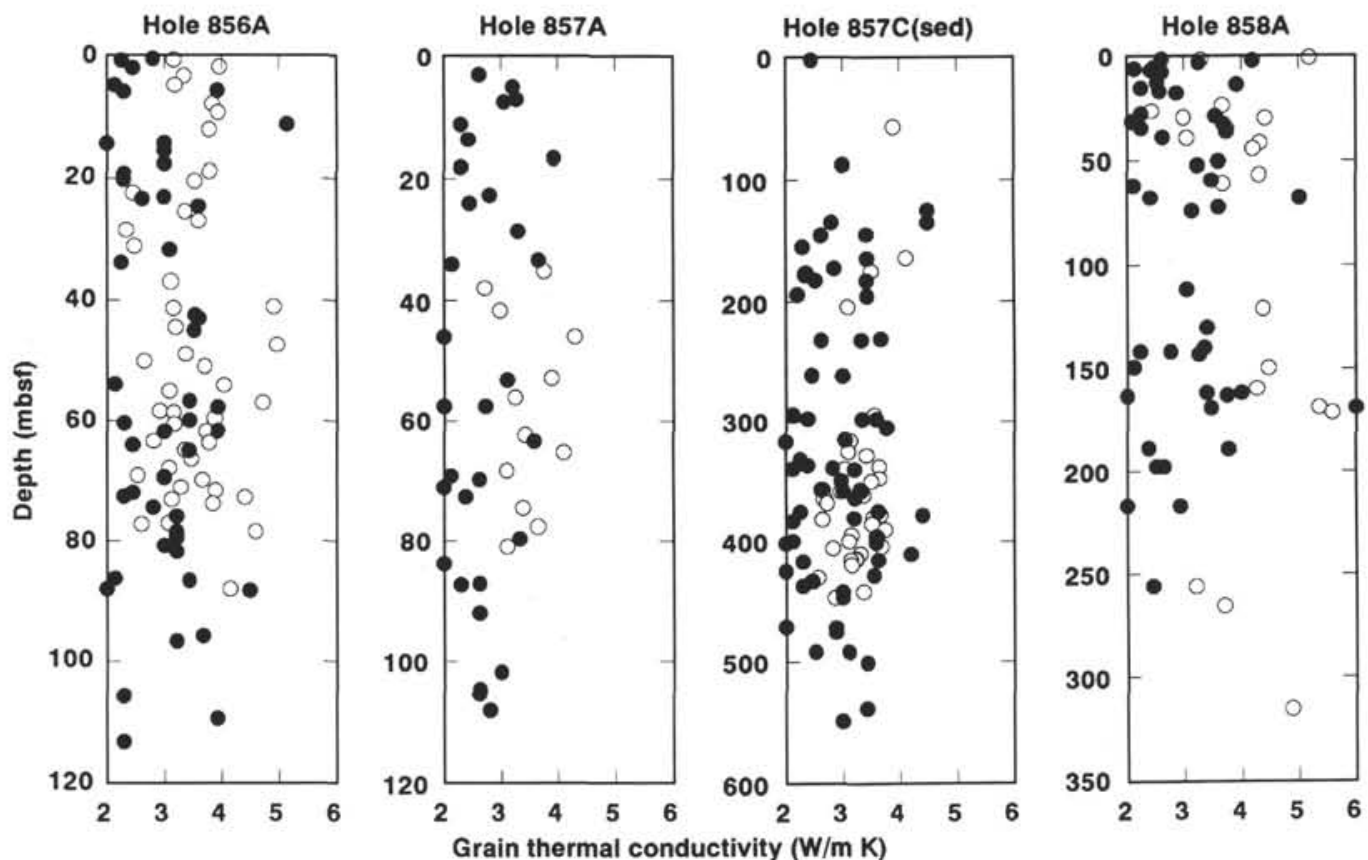

Figure 3. Estimated grain thermal conductivity vs. depth for Holes $856 \mathrm{~A}, 857 \mathrm{~A}, 857 \mathrm{C}$ (sedimentary part), and $858 \mathrm{~A}$. Open circles $=$ estimation by the geometric mean model (point-by-point method); solid circles = estimation from the mineral composition.

measurements. Standard error and drift rate should be especially good evaluators for checking the reliability of measurement. Thus, correlations are made between thermal conductivity and these factors, as plotted in Figure 5. Only the points where grain conductivities can be calculated are included (i.e., data used are similar to those used in Figure 2).
Figure 5 indicates that populations at all holes are not separable from each other. Hole $858 \mathrm{~A}$, which has relatively high conductivity values, does not show any particularity in these plots. Although not shown here, other factors were tested and did not reflect a difference. Therefore, high grain conductivity at Hole $858 \mathrm{~A}$ cannot be attributed to measurement errors. 

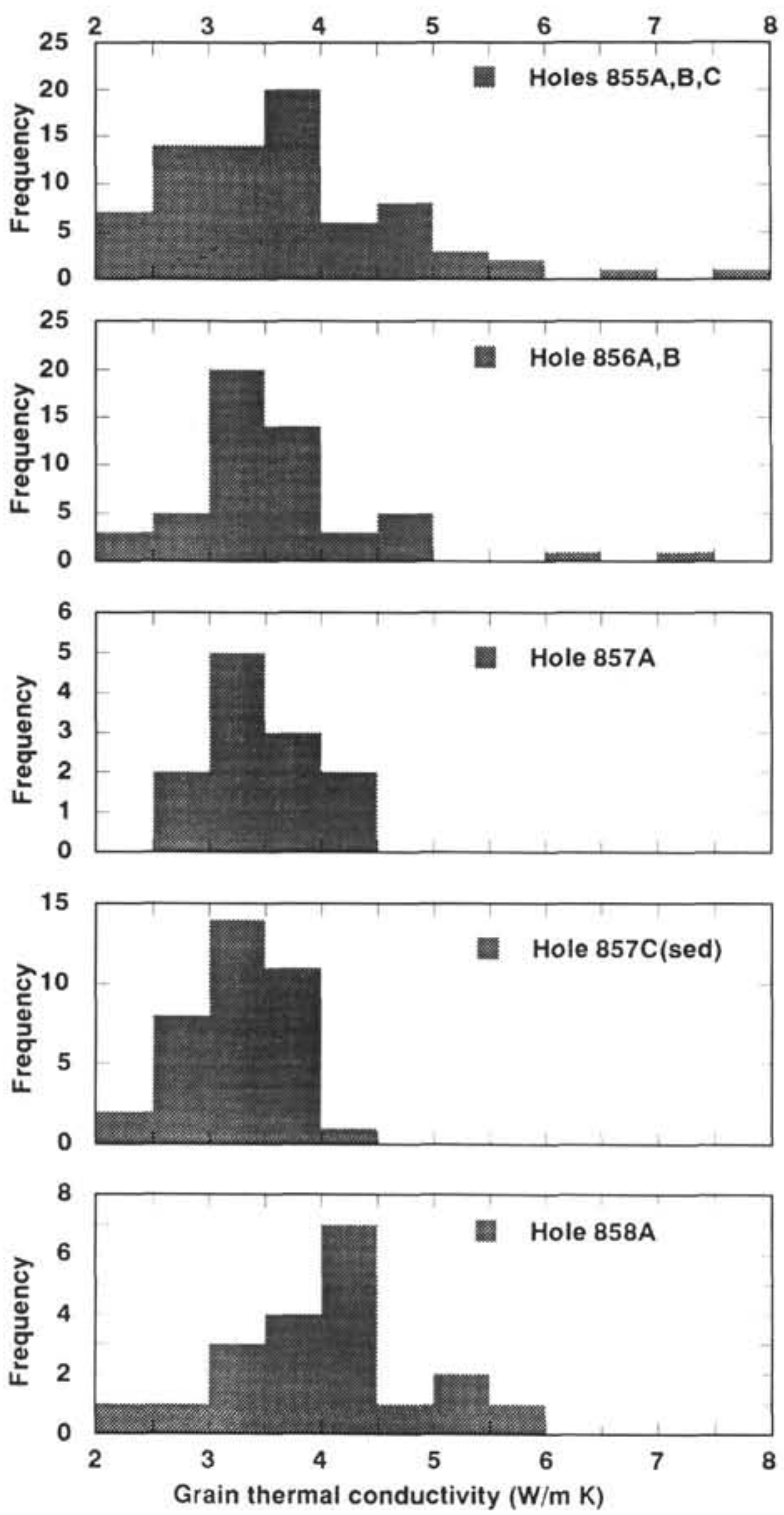

Figure 4 . Histograms of the grain conductivity distribution estimated by the point-by-point method for Holes 855 (A, B, and C), 856 ( $A$ and B), 857 A, 857C (sedimentary part), and 858A. Values are binned at every $0.5 \mathrm{~W} /(\mathrm{m} \cdot \mathrm{K})$.

\section{ESTIMATION OF GRAIN CONDUCTIVITY AND GRAIN DENSITY FROM SMEAR-SLIDE DESCRIPTION}

Mineral composition was roughly determined using smear slides with an accuracy of ca. 10\% (Shipboard Scientific Party, 1992f). For Sites 855,856 , and 857 , variation of chemical composition of sediment samples is mainly attributed to the original compositional differences and the effects of hydrothermal metamorphism. Compositional differences are dominant in parts shallower than $400 \mathrm{~m}$ below sea floor (mbsf) at Site 857.

Usually sediment consists of porous polymineral aggregates, including pore fluid. In this case, the "bulk" grain conductivity $K_{g}$ in Equation 1 can be replaced with:

$$
K_{g}=\underset{j=1}{m} K_{j}^{\phi},
$$

Table 2. Density and conductivity of minerals.

\begin{tabular}{lcc}
\hline \multicolumn{1}{c}{ Mineral } & $\begin{array}{r}\text { Density } \\
\left(\mathrm{g} / \mathrm{cm}^{3}\right)\end{array}$ & $\begin{array}{c}\text { Thermal conductivity } \\
(\mathrm{W} /[\mathrm{m} \cdot \mathrm{K}])\end{array}$ \\
\hline Albite & 2.62 & 2.15 \\
Anhydrite & 2.96 & 4.76 \\
Anorthite & 2.76 & 1.68 \\
Calcite & 2.71 & 3.57 \\
Chlorite & 2.78 & 2.00 \\
Feldspar & 2.65 & 2.00 \\
Illite & 2.66 & 2.00 \\
Magnetite & 5.20 & 5.10 \\
Microcline & 2.56 & 2.49 \\
Orthoclase & 2.57 & 2.31 \\
Plagioclase & 2.70 & 1.64 \\
Pyrite & 5.01 & 19.20 \\
Pyrrhotite & 4.83 & 4.60 \\
Quartz & 2.65 & 7.69 \\
\hline
\end{tabular}

where $K_{j}$ is the conductivity of $\mathrm{j}$-th individual component of the mineral and $\phi_{j}$ is the volumetric fraction of the $\mathrm{j}$-th component (Brigaud and Vasseur, 1989). Also, the grain density can be estimated in an arithmetic mean form from $\phi_{j}$ and the density of each mineral.

Assuming that a mineral composition determined by the smear slides is the volume fraction of each mineral, it can be used to estimate grain thermal conductivity and grain density according to the above equations. Although the data are generally unreliable for quantitative analyses, this would be valid within the $10 \%$ accuracy which is originally included in the data. The density and thermal conductivity values for each mineral that were used to calculate grain conductivity and density are listed in Table 2, according to Brigaud and Vasseur (1989), Sass (1965), and Horai (1971). Some minerals that are not dominant have been neglected.

Calculated values are plotted vs. depth in Figure 3 (solid circles). They are averaged throughout the core at each hole, and are shown in Table 1. The average composition of clay and quartz are ca. $30 \%$ $( \pm 30 \%)$ and $23 \%( \pm 17 \%)$, respectively; values are statistically indistinguishable at all sites. Densities and thermal conductivities are also quite uniform among sites within the limit of errors. The observations suggest that the variations of grain conductivity and grain density are not the result of variations in mineral composition.

Grain conductivities determined from porosity and measured conductivity $\left(\mathrm{K}_{\mathrm{g}}\right.$, around $\left.3.5 \mathrm{~W} /[\mathrm{m} \cdot \mathrm{K}]\right)$ seem to be systematically higher than those estimated using the smear-slide mineralogy, porosity, and the geometric mean model $\left(K_{g, s m}\right.$, around $\left.3.0 \mathrm{~W} /[\mathrm{m} \cdot \mathrm{K}]\right)$, as can be seen in Figure 3. Calculated average densities $\rho_{g, s m}$ (around $2.7 \mathrm{~g} / \mathrm{cm}^{3}$ ) also seem to be systematically lower than those determined from index property measurement $\left(\rho_{g}\right.$, Shipboard Scientific Party, 1992a). In order to confirm this difference, correlations of $\mathrm{K}_{g, s m}$ vs. $\mathrm{K}_{\mathrm{g}}$ and $\rho_{g, s m}$ vs. $\rho_{g}$ have been taken point-by-point, respectively. Since sampling locations are not exactly the same among smear slides, index properties, and thermal conductivities, they are correlated within a window of $\pm 5 \mathrm{~cm}$ width. Figure 6 is the correlative plots for Holes 856A, 857A, 857C (sedimentary part only), and $858 \mathrm{~A}$, showing that both $\mathrm{K}_{g}$ and $\rho_{g}$ are higher than those estimated from smear slides, though no correlation between $\mathrm{K}_{g}$ and $K_{g, s m}$ and between $\rho_{g}$ and $\rho_{g, s m}$ is seen.

Due to the ambiguity involved in determining mineral composition by smear slides, it is difficult to discuss the cause of general low grain density and conductivity values for samples from Leg 139 in more detail. These values may be the result of regional hydrothermal metamorphism, making a comparative study in nonhydrothermal areas necessary.

\section{DISCUSSION AND CONCLUSIONS}

Grain thermal conductivities were estimated from thermal conductivity and porosity data measured for hydrothermally altered turbidite sediments in Middle Valley, northern Juan de Fuca Ridge. 

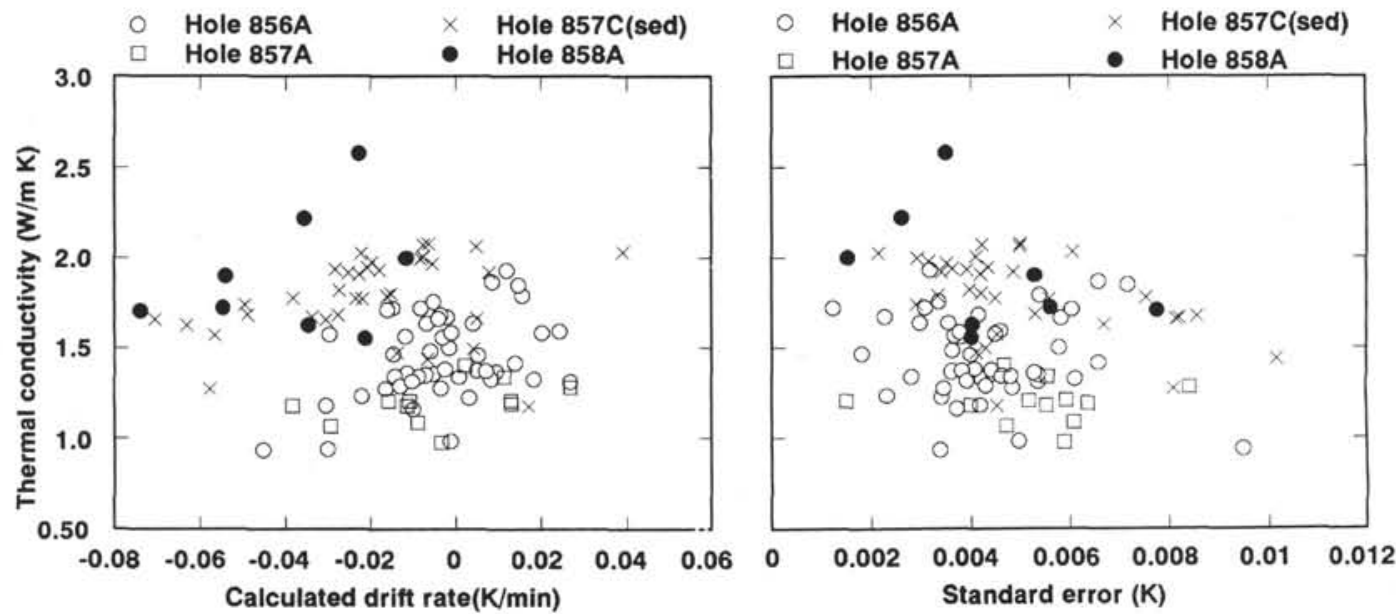

Figure 5. Correlative plots of measured thermal conductivity vs. calculated drift rate and standard error of needle-probe temperature during measurements for Holes 856A, 857A, 857C (sedimentary part), and 858A. Only the points where grain conductivities can be calculated are included (i.e., data used are similar to those used in Fig. 2).
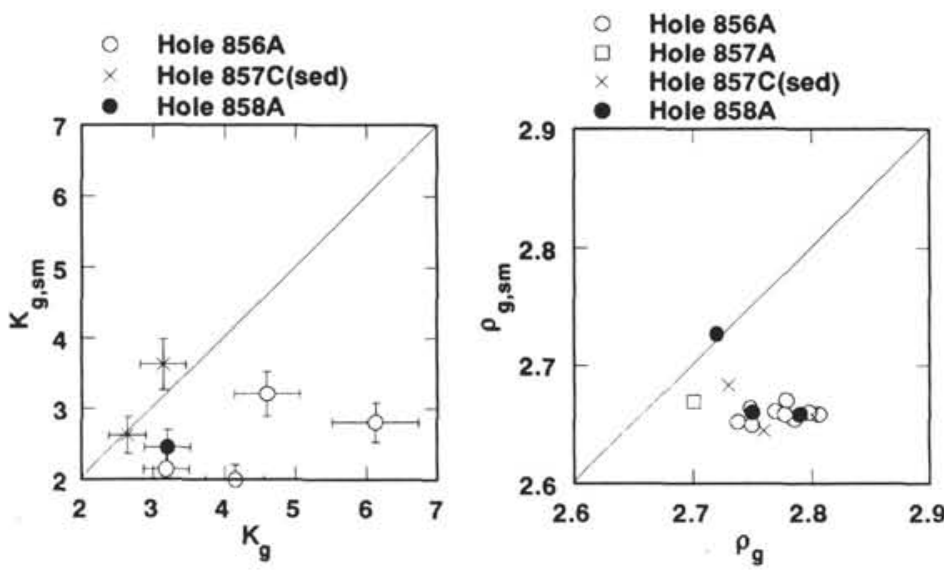

Figure 6. Correlations of $\mathrm{K}_{g, s m}$ vs. $\mathrm{K}_{g}$ and $\rho_{g, s m}$ vs. $\rho_{\mathrm{g}}$ for Holes $856 \mathrm{~A}$, $2.9 \quad 857 \mathrm{~A}, 857 \mathrm{C}$ (sedimentary part), and $858 \mathrm{~A}$. Cross bars attached indicate the $10 \%$ error range,
Although they have large scatter, careful examination of the data suggests that the average (or main population of) grain conductivity at Hole 858A, located at the edge of the hydrothermal vent area, is higher by more than $0.5 \mathrm{~W} /(\mathrm{m} \cdot \mathrm{K})$ than that at other holes. This difference cannot be attributed either to the measurement error of thermal conductivities or to differences in mineral composition.

Samples from Hole 856A (Unit IIA), 857A (Unit IIA), and 858A (Unit IIA and upper part of Unit IIC cored by HPC method), which consist of only weakly indurated hemipelagic and turbiditic sediments (Shipboard Scientific Party, 1992b, c and d), have similar grain conductivity values (around $3.5 \mathrm{~W} /[\mathrm{m} \cdot \mathrm{K}]$ ) (Table 1 ).

On the other hand, samples from Holes 857C (Unit IIB) and 858A$\mathrm{X}$ (Unit IIC) are moderately to well-indurated hemipelagic and turbiditic sediments with carbonate concretions or cementation volumetrically important (Shipboard Scientific Party, 1992e). However, the grain conductivity values at Hole $857 \mathrm{C}$ and Hole $858 \mathrm{~A}-\mathrm{X}$ are $3.1 \mathrm{~W} /(\mathrm{m} \cdot \mathrm{K})$ and $4.4 \mathrm{~W} /(\mathrm{m} \cdot \mathrm{K})$, respectively. Since Hole $857 \mathrm{C}$ and Site 855 have been cored by the RCB method, estimated grain conductivity values may be affected by the coring disturbance, resulting in large error. This may be the cause for the difference between Holes $857 \mathrm{C}$ and $858 \mathrm{~A}$.

According to sediment alteration and geochemistry data (Shipboard Scientific Party, 1992d), carbonate concretions occur between 20 mbsf and 62 mbsf (similar to the range of HPC coring) and anhydrite concretions below $62 \mathrm{mbsf}$ in Hole $858 \mathrm{~A}$. The difference in local mineral composition mentioned above may be the cause for high grain conductivity at Hole $858 \mathrm{~A}-\mathrm{X}$. The higher value at Site 858 may reflect the influence of induration or cementation due to hydrothermal fluid flow at that site. Grain conductivities and grain densities are higher at all sites than those expected from mineral composition, perhaps due to regional hydrothermal metamorphism.

Various problems still remain unsolved as to the effect of physical and chemical mechanisms of hydrothermal activity such as induration, cementation, and lithification, on thermal conductivity. These factors may cause the geometric-mean relationship between thermal conductivity and porosity to be invalid. To resolve these problems, a laboratory experiment would be necessary as well as a comparative study in an area that is not hydrothermally affected.

\section{ACKNOWLEDGMENTS}

I am grateful to Leg 139 co-chief scientists, Earl E. Davis and Mike J. Mottl, to Leg 139 staff scientist, Andy T. Fisher, and also to the physical property scientists, Heiner W. Villinger, Henny M. Gröschel-Becker, and Boris A. Konyukhov for cooperative work during the cruise.

\section{REFERENCES*}

Brigaud, F., and Vasseur, G., 1989. Mineralogy, porosity and fluid control on thermal conductivity of sedimentary rocks. Geophys. J., 98:525-542.

\footnotetext{
- Abbreviations for names of organizations and publications in ODP reference lists follow the style given in Chemical Abstracts Service Source Index (published by American Chemical Society).
} 
Davis, E.E., and Villinger, H., 1992. Tectonic and thermal structure of the Middle Valley sedimented rift, northern Juan de Fuca Ridge. In Davis, E.E., Mottl, M.J., Fisher, A.T., et al., Proc. ODP, Init. Repts., 139: College Station, TX (Ocean Drilling Program), 9-41.

Horai, K., 1971. Thermal conductivity of rock-forming minerals. J. Geophys. Res., 76:1278-1308.

, 1981. Thermal conductivity of sediments and igneous rocks recovered during Deep Sea Drilling Project Leg 60. In Hussong, D.M., Uyeda, S., et al., Init. Repts. DSDP, 60: Washington (U.S. Govt. Printing Office), $807-834$.

Sass, J.H., 1965. The thermal conductivity of fifteen feldspar specimens. $J$. Geophys. Res., 70:4064-4065.

Shipboard Scientific Party, 1992a. Explanatory notes. In Davis, E.E., Mottl, M.J., Fisher, A.T., et al., Proc. ODP, Init. Repts., 139: College Station, TX (Ocean Drilling Program), 55-97.

1992b. Site 855. In Davis, E.E., Mottl, M.J., Fisher, A.T., et al., Proc. ODP, Init. Repts., 139: College Station, TX (Ocean Drilling Program), 101-160. 1992c. Site 856. In Davis, E.E., Mottl, M.J., Fisher, A.T., et al., Proc. ODP, Init. Repts., 139: College Station, TX (Ocean Drilling Program), 161-281.

1992d. Site 857. In Davis, E.E., Mottl, M.J., Fisher, A.T., et al., Proc. ODP, Init. Repts., 139: College Station, TX (Ocean Drilling Program), 283-429.

1992e. Site 858. In Davis, E.E., Mottl, M.J., Fisher, A.T., et al., Proc. ODP, Init. Repts., 139: College Station, TX (Ocean Drilling Program), 431-569.

, 1992f. Section 4: Smear slides. In Davis, E.E., Mottl, M.J., Fisher, A.T., et al., Proc. ODP, Init. Repts., 139: College Station, TX (Ocean Drilling Program), 933-946.

Date of initial receipt: 8 March 1993

Date of acceptance: 22 October 1993

Ms 139SR-250 